\title{
SERVICE QUALITY AND ITS DIMENSIONS OF DIGITAL BANKING: A QUANTITATIVE STUDY
}

\section{A. Cyano Prem}

Ph.D. Research Scholar, Bharathidasan School of Management, Bharathidasan University, Tiruchirappalli, Tamilnadu, India

\section{Dr. M. Babu}

Assistant Professor, Bharathidasan School of Management, Bharathidasan University, Tiruchirappalli, Tamilnadu, India

\section{R. Sugirtha}

Ph.D. Research Scholar, Bharathidasan School of Management, Bharathidasan University, Tiruchirappalli, Tamilnadu, India

\section{R. Muneeswaran}

Ph.D. Research Scholar, Bharathidasan School of Management, Bharathidasan University, Tiruchirappalli, Tamilnadu, India

\begin{abstract}
The study analysed the relationship between Service Quality and its dimensions of Digital Banking and Payment Applications in India. This paper was based on primary data, collected from digital banking users through online questionnaires, in Tamil Nadu and Karnataka. Statistical tools, like Descriptive statistics, $t$ - test, ANOVA, Pearson Correlation and Multiple Regression were used to compare the effects of various demographic factors on Service Quality and to find the relationship between Service Quality Dimensions. The demographic factors did not have any significant effect on Service Quality. Private Sector Bank Users rated more Service Quality than Public Sector Bank Users. Security, Responsiveness and Technical Reliability explained more variability in Service Quality than other dimensions. Security was the most significant predictor of Service Quality, followed by Responsiveness and Technical Reliability.
\end{abstract}

Key words: Digital Banking, Service Quality, ANOVA, Multiple Regression, SPSS

Cite this Article: A. Cyano Prem, M. Babu, R. Sugirtha and R. Muneeswaran, Synergy of Banks' Amalgamation and Loaning by Small Agro-Based Firms: Evidence from Nigeria, International Journal of Management, 11(12), 2020, pp 1119-1127.

http://iaeme.com/Home/issue/IJM?Volume=11\&Issue=12 


\section{INTRODUCTION}

Cashless transfers and digital payment methods are increasing day by day. The main channels are Debit Cards and Credit Cards through POS, Internet Banking through IMPS, NEFT and RTGS and Payment Wallets and Applications through UPI. The Payment Applications like Google Pay, Paytm and Phone Pay are the most used UPI transfer Applications. The COVID19 pandemic has accelerated the use of contactless payments as well. Thus, even small vendors are using these payment applications to receive payments. The transfer of small amounts has become more comfortable. Thus, the study of the dimensions affecting service quality can give insights on how to improve the applications and services offered by banks and payment companies. This paper investigates the relationship between service quality and its dimensions of digital payments.

\section{REVIEW OF LITERATURE}

Rashed, A. K. \& Tabassum. C. (2014) analysed five dimensions in service quality like tangibility, reliability, responsiveness, empathy, and assurance with the help of regression analysis on primary data. Results of the study concluded that the dimensions significantly influenced customer attitude towards satisfaction with positive correlation. It was concluded that service quality dimensions are important for customer satisfaction in Bangladesh banks.

Rand, G. and Tsoukatos, E (2006) examined the path leading from Service Quality to Customer Satisfaction to Loyalty, at the level of constructs. The study was done on Greek Insurance Companies. A model similar to SERVQUAL was developed for this study. Confirmatory and exploratory factor analysis were used to determine the dimensions of the scale. The scales were not confirmed. The study identified that tangibles did not affect customer satisfaction and repurchasing intentions.

Parasuraman, A., Zeithaml, V. A. and Berry, L. L. (1985) attempted to redefine the tangibles as a dimension in service quality because many services did not have any tangibles. An extensive exploratory study was conducted on quality in four different services and a new model was developed.

Oliver, R. L. (1993) highlighted the criticisms of SERVQUAL model from empirical and conceptual viewpoints. This study added another dimension called 'satiated customer'. There can be such a type of customer with complete satisfaction but would like to switch to another service provider due to high turnaround time. The study suggests that understanding adaptation and constant innovation are crucial.

Negi, R. (2009) determined customer satisfaction through perceived service quality in Africa. Primary data were computed and it revealed that service quality gaps between perception and expectation negatively influenced the dimensions. The study also ranked Network Quality as the highest predictor and Tangibles as the least significant predictor of Service Quality. The analysis also concluded that customer value also contributed to overall customer satisfaction.

Ladhari, R. (2008) identified and discussed the empirical and conceptual issues in alternatives for SERVQUAL scale. The study identified the limitations of alternate scales. However, these limitations did not invalidate the scales.

Duff, A., Hair, M. \& Guo, X. (2008) constructed a scale to capture service quality in Chinese corporate banks. The factor analysis, done on primary data, was measured by a nested model, which contains two higher order constructs like functional quality and technical quality and four lower order dimensions including reliability, human capital, communication and technology. 
Chang, J. C. (2008) researched the tourists' perception of Service Quality in Guided Packaged Tours. The study used qualitative approach for gaining insights into tourists' views. The study found that 'tangibility' was less significant when compared with other dimensions of service quality. Dimensions like 'communication' and 'sociability' were important to the travel industry.

From the above extant literature, the present study selected six service quality dimensions, namely Responsiveness, Technical Reliability, Security, Design, Performance and Incentives for finding their relationship with service quality.

\section{OBJECTIVES OF THE STUDY}

The present study examined the relationship between Service Quality and its dimensions of Digital Payments.

- To analyse the effect of demographic factors like Gender, Income and Education on Service Quality

- To test the difference in Service Quality ratings given by Public and Private Sector Bank Users

- To analyse the relationship between Service Quality and its Dimensions

Hypotheses of the Study: This study has the following null hypotheses to be tested in the study.

$\mathbf{N H}_{01}$ : There is no difference in the Service Quality regarding Gender

$\mathbf{N H}_{\mathbf{0 2}}$ : There is no difference in the Service Quality between Public Sector Bank Users and Private Sector Bank Users

$\mathbf{N H}_{\mathbf{0 3}}$ : There is no difference in the Service Quality regarding Educational Qualification

$\mathbf{N H}_{\mathbf{0 4}}$ : There is no difference in the Service Quality regarding Income Levels

NH $_{05}$ : There is no correlation between Service Quality, Responsiveness, Technical Reliability, Security, Design, Performance and Incentives

NH $_{06}$ : There is no relationship between Service Quality (Dependent Variable) and Responsiveness, Technical Reliability, Security, Design, Performance and Incentives (Independent Variables)

\section{METHODOLOGY}

Service Quality dimensions like Responsiveness, Technical Reliability, Security, Design, Performance and Incentives were selected after literature review and discussing with target customer groups like digital payment users and shop vendors. The study examined the relationship between service quality and its dimensions of digital banking. The study also analysed the effects of demographic factors like gender, income and education on service quality. This paper was based on primary data. An online survey questionnaire was sent to various known circles on convenient basis and public groups as well. A total of 166 respondents completed the survey. Descriptive statistics, $t$ - test, ANOVA, Pearson Correlation and Multiple Regression were used to compare the effect of various demographic factors and their relationship with service quality dimensions. 


\section{ANALYSIS AND DISCUSSION}

Table 1 Levene's Test for Homogeneity of Variances of Males and Females on Service Quality

\begin{tabular}{|l|c|c|}
\hline \multirow{2}{*}{} & \multicolumn{2}{|c|}{ Levene's Test } \\
\cline { 2 - 3 } & $\mathbf{F}$ & $\mathbf{p}$ \\
\hline Service & .03 & .86 \\
\hline
\end{tabular}

Source: Primary Data, computed using SPSS

Levene's test checks whether the variances of two samples are approximately equal. This is the main assumption for conducting $t$ tests. Since $p=.86(p>.01)$, the assumption of homogeneity of variance has been met. The variances are equal.

Table 2 t-test Results Comparing Males and Females on Service Quality

\begin{tabular}{|l|c|c|c|c|c|c|c|}
\hline \multicolumn{1}{|c|}{ Gender } & N & Mean & SD & t value & t critical & df & p \\
\hline Male & 91 & 3.84 & .69 & .79 & 1.65 & 164 & .43 \\
\hline Female & 75 & 3.76 & .69 & & & & \\
\hline
\end{tabular}

The $\mathrm{t}$ value calculated $(\mathrm{t}=.79)$ was less than $\mathrm{t}$ critical $(\mathrm{t}$ critical $=1.65)$ with degrees of freedom being 164. The $\mathrm{p}$ value $(\mathrm{p}=.43)$ was greater than .05 and the test was nonsignificant. The groups did not differ significantly, $\mathrm{t}(164)=.79, \mathrm{p}=.43$. The mean for males $(\mathrm{M}=3.84, \mathrm{SD}=.69)$ was not significantly different from females $(\mathrm{M}=3.76, \mathrm{SD}=.69)$. These findings did not support the idea that there was difference in service quality with gender.

Table 3 Levene's Test for Homogeneity of variances of Public Sector Bank Users and Private Sector Bank Users on Service Quality

\begin{tabular}{|l|c|c|}
\hline \multirow{2}{*}{} & \multicolumn{2}{|c|}{ Levene's Test } \\
\cline { 2 - 3 } & F & p \\
\hline Service & 5.95 & .02 \\
Quality & & \\
\hline
\end{tabular}

Source: Primary Data, computed using SPSS

Levene's test checks whether the variances of two samples are approximately equal. This is the main assumption for conducting t tests. Since $p=.02$ was slightly greater than .01 the assumption of homogeneity of variance has been met. Since sample size is greater than $30(\mathrm{~N}$ $>30$ ) and the same sizes of both the groups were equal $t$ test was Robust towards type 1 error (Rejection of correct Null Hypothesis). So, we can assume that the variances were almost equal.

Table 4 t-test Results Comparing Public Sector Bank Users and Private Sector Bank Users on Service Quality

\begin{tabular}{|l|c|c|c|c|c|c|c|}
\hline \multicolumn{1}{|c|}{ Bank } & N & Mean & SD & t value & t critical & df & p \\
\hline $\begin{array}{l}\text { Public Sector } \\
\text { Bank Users }\end{array}$ & 83 & 3.68 & .76 & -2.26 & -1.65 & 164 & .025 \\
\hline $\begin{array}{l}\text { Private Sector } \\
\text { Bank Users }\end{array}$ & 83 & 3.92 & .60 & & & & \\
\hline
\end{tabular}

Source: Primary Data, computed using SPSS

The $t$ value calculated $(t=-2.26)$ was less than $t$ critical $(t$ critical $=-1.65)$ for degrees of freedom at 164 . The $\mathrm{p}$ value $(\mathrm{p}=.025)$ was less than .05 , the test was significant at $95 \%$ confidence interval. The groups differed significantly, $t(164)=-2.26, p=.025$. The mean for 
Public Sector Bank Users $(\mathrm{M}=3.68, \mathrm{SD}=.76)$ was significantly lesser than Private Sector Bank Users $(\mathrm{M}=3.92, \mathrm{SD}=.60)$. In other words, Private Sector Bank Users had rated higher service quality than Public Sector Bank Users.

Table 5 Descriptive Statistics for Educational Qualification on Service Quality

\begin{tabular}{|l|c|c|c|}
\hline \multicolumn{1}{c|}{$\begin{array}{c}\text { Educational } \\
\text { Qualification }\end{array}$} & N & Mean & SD \\
\hline School Level & 56 & 3.80 & .64 \\
\hline Undergraduate & 76 & 3.72 & .72 \\
\hline Postgraduate & 34 & 4.00 & .69 \\
\hline
\end{tabular}

Source: Primary Data, computed using SPSS

Descriptive Statistics for different educational qualifications like school level $(\mathrm{M}=3.80$, $\mathrm{SD}=.64)$, undergraduate $(\mathrm{M}=3.72, \mathrm{SD}=.72)$ and postgraduate $(\mathrm{M}=4.00, \mathrm{SD}=.69)$.

Table 6 Levene's Test for Homogeneity of Variances among different Educational Qualification levels on Service Quality

\begin{tabular}{|l|c|c|}
\hline \multirow{2}{*}{} & \multicolumn{2}{|c|}{ Levene's Test } \\
\cline { 2 - 3 } Service & F & p \\
Quality & .42 & .65 \\
\hline
\end{tabular}

Source: Primary Data, computed using SPSS

Levene's test checks whether the variances of the samples are approximately equal. This is the main assumption for conducting ANOVA. Since $p=.65(p>.01)$ and hence were nonsignificant, the assumption of homogeneity of variance was met. The variances are almost equal.

Table 7 One-way ANOVA Comparing different Educational Qualification levels on Service Quality

\begin{tabular}{|l|c|c|c|c|c|}
\hline & $\begin{array}{c}\text { Sum of } \\
\text { Squares }\end{array}$ & df & $\begin{array}{c}\text { Mean } \\
\text { Square }\end{array}$ & F & p \\
\hline $\begin{array}{l}\text { Between } \\
\text { Groups }\end{array}$ & 1.79 & 2 & .89 & 1.87 & .15 \\
\hline Within Groups & 78.03 & 163 & .47 & & \\
\hline Total & 79.83 & 165 & & & \\
\hline
\end{tabular}

Source: Primary Data, computed using SPSS

There was no significant difference among the three types of educational qualification levels on service quality, $\mathrm{F}(2,163)=1.87, \mathrm{p}=0.15, \mathrm{p}>0.05$; There was no significant difference on service quality regarding education.

Table 8 Descriptive Statistics for Income on Service Quality

\begin{tabular}{|l|c|c|c|}
\hline \multicolumn{1}{|c|}{ Income } & $\mathbf{N}$ & Mean & SD \\
\hline Up to 25,000 & 40 & 3.82 & .78 \\
\hline $25,001-50,000$ & 40 & 3.77 & .65 \\
\hline $50,001-1,00,000$ & 33 & 3.75 & .56 \\
\hline Above $1,00,000$ & 53 & 3.80 & .74 \\
\hline
\end{tabular}

Source: Primary Data, computed using SPSS

Descriptive Statistics for different income levels like Up to 25,000 $(\mathrm{M}=3.82, \mathrm{SD}=.78)$, $25,001-50,000(\mathrm{M}=3.77, \mathrm{SD}=.65), 50,001-1,00,000(\mathrm{M}=3.75, \mathrm{SD}=.56)$ and Above $1,00,000(\mathrm{M}=3.80, \mathrm{SD}=.74)$. 
Table 9 Levene's Test for Homogeneity of Variances among different Educational Qualification levels on Service Quality

\begin{tabular}{|l|c|c|}
\hline \multirow{2}{*}{} & \multicolumn{2}{|c|}{ Levene's Test } \\
\cline { 2 - 3 } & F & p \\
\hline Service & .42 & .73 \\
Quality & & \\
\hline
\end{tabular}

Source: Primary Data, computed using SPSS

Levene's test checks whether the variances of the samples are approximately equal. This is the main assumption for conducting ANOVA. Since $p=.73(p>.01)$ and hence nonsignificant, the assumption of homogeneity of variance was met. The variances were almost equal.

Table 10 One-way ANOVA Comparing different Educational Qualification levels on Service Quality

\begin{tabular}{|l|c|c|c|c|c|}
\hline & $\begin{array}{c}\text { Sum of } \\
\text { Squares }\end{array}$ & df & $\begin{array}{c}\text { Mean } \\
\text { Square }\end{array}$ & F & p \\
\hline Between Groups & .23 & 3 & .076 & .155 & .93 \\
\hline Within Groups & 79.60 & 162 & .49 & & \\
\hline Total & 79.83 & 165 & & & \\
\hline
\end{tabular}

Source: Primary Data, computed using SPSS

There was no significant difference among the income levels on service quality, $\mathrm{F}(3,162)$ $=.155, \mathrm{p}=0.93, \mathrm{p}>0.05$; There was no significant difference on service quality regarding income.

Table 11 Descriptive Statistics for Service Quality and its Factors

\begin{tabular}{|l|c|c|c|}
\hline \multicolumn{1}{|c|}{ Variables } & N & Mean & SD \\
\hline Responsiveness & 166 & 3.34 & .84 \\
\hline $\begin{array}{l}\text { Technical } \\
\text { Reliability }\end{array}$ & 166 & 3.50 & .87 \\
\hline Security & 166 & 3.60 & .89 \\
\hline Design & 166 & 3.90 & .86 \\
\hline Performance & 166 & 3.68 & .87 \\
\hline Incentives & 166 & 2.96 & .94 \\
\hline Service Quality & 166 & 3.80 & .69 \\
\hline
\end{tabular}

Source: Primary Data, computed using SPSS

Descriptive Statistics for service quality and other factors. Responsiveness ( $M=3.34$, SD $=.84)$, Technical Reliability $(\mathrm{M}=3.50, \mathrm{SD}=.87)$, Security $(\mathrm{M}=3.60, \mathrm{SD}=.89)$, Design $(\mathrm{M}$ $=3.90, \mathrm{SD}=.86)$, Performance $(\mathrm{M}=3.68, \mathrm{SD}=.87)$, Incentives $(\mathrm{M}=2.96, \mathrm{SD}=.94)$ and Service Quality $(\mathrm{M}=3.80, \mathrm{SD}=.69)$

Table 12 Pearson Correlation for Service Quality and other Factors

\begin{tabular}{|l|c|c|c|c|c|c|c|}
\hline & RS & TR & SE & DS & PF & IN & SQ \\
\hline Responsiveness (RS) & & $.55^{* *}$ & $.46^{* *}$ & $.45^{* *}$ & $.41^{* *}$ & $.27^{* *}$ & $.49^{* *}$ \\
\hline Technical Reliability (TR) & & & $.64^{* *}$ & $.66^{* *}$ & $.63^{* *}$ & $.39^{* *}$ & $.61^{* *}$ \\
\hline Security (SE) & & & & $.62^{* *}$ & $.57^{* *}$ & $.25^{* *}$ & $.57^{* *}$ \\
\hline Design (DS) & & & & & $.63^{* *}$ & $.32^{* *}$ & $.54^{* *}$ \\
\hline Performance (PF) & & & & & & $.33^{* *}$ & $.53^{* *}$ \\
\hline Incentives (IN) & & & & & & $.33^{* *}$ \\
\hline Service Quality (SQ) & & & & & & \\
\hline
\end{tabular}

Source: Primary Data, computed using SPSS

Note. ${ }^{* *}$ Correlation is statistically significant at the .01 level 
A Pearson product-moment correlation was conducted to examine the relationship between Service Quality, Responsiveness, Technical Reliability, Security and Privacy, Application Design, Performance and Incentives for Digital Banking Services and Payment Applications. Service Quality was more strongly positively related to Technical Reliability, $r$ $(166)=.61, p<.001$, than other factors like Security, $r(166)=.57, p<.001$ and Design, $r$ $(166)=.57, \mathrm{p}<.001$. Incentives, $\mathrm{r}(166)=.33, \mathrm{p}<.001$ showed the least correlation with Service Quality. Although all the correlations were significant at the .01 level. Design and Technical Reliability showed the highest correlation, $\mathrm{r}(166)=.66, \mathrm{p}<.001$ while Security and Incentives showed the least correlation coefficient, $r(166)=.25, p<.001$. These findings indicated that Technical Reliability and Security could explain much more of the variability in Service Quality than Incentives and Design. The effect size for Technical Reliability $\left(r^{2}=\right.$ $.61)$ and Security $\left(r^{2}=.57\right)$ indicated that the levels of Technical Reliability $(61 \%)$ and Security (57\%) accounted for large portion of variability in Service Quality.

Table 13 Durbin Watson Test for Independence of Observations among Predictor Variables on Service Quality

\begin{tabular}{|c|c|}
\hline Durbin - Watson & $\mathbf{p}$ \\
\hline 1.83 & $\mathrm{P}<.01$ \\
\hline \multicolumn{2}{|c|}{ Source: Primary Data, computed using SPSS }
\end{tabular}

Durbin - Watson Test shows independence of observations. The value of 1.83 (greater than 1 and lesser than 3) shows the predictors like Responsiveness, Technical Reliability, Security, Design, Performance and Incentives to be not strongly correlated. Thus, they predicted different amounts of variability in service quality.

Table 14 Regression Model Summary

\begin{tabular}{|c|c|}
\hline $\mathbf{R}$ & R square \\
\hline .69 & .47 \\
\hline
\end{tabular} Source: Primary Data, computed using SPSS

A value of $\mathrm{R}=.69$ indicates a good level of prediction. The $\mathrm{R}$ Square also called as the coefficient of determination is the proportion of variance in the dependent variable that can be explained by the independent variables. $R^{2}=.47$ indicated that $47 \%$ variability of the Service Quality can be explained by Responsiveness, Technical Reliability, Security and Privacy, Application Design, Performance and Incentives.

Table 15 ANOVA Table for the Regression Model

\begin{tabular}{|l|c|c|c|c|c|}
\hline \multicolumn{1}{|c|}{ Model } & $\begin{array}{c}\text { Sum of } \\
\text { Squares }\end{array}$ & $\mathbf{d f}$ & $\begin{array}{c}\text { Mean } \\
\text { Square }\end{array}$ & F & p \\
\hline Regression & 38.15 & 6 & 6.35 & 24.25 & $\mathrm{p}<.001$ \\
\hline Residual & 41.67 & 159 & .26 & & \\
\hline Total & 79.83 & 165 & & & \\
\hline \multicolumn{5}{c}{ Source: Primary Data, computed using SPSS } \\
\end{tabular}

The $\mathrm{F}$ value in the ANOVA table tests whether the overall regression model is a good fit for the data. $F(6,159)=24.25, \mathrm{p}<.01$. The Table shows that the independent variables like Responsiveness, Technical Reliability, Security, Design, Performance and Incentives statistically significantly predicted Service Quality. The regression model was a good fit of the data. 
A. Cyano Prem, M. Babu, R. Sugirtha and R. Muneeswaran

Table 16 Collinearity Statistics

\begin{tabular}{|l|c|c|}
\hline & Tolerance & VIF \\
\hline (Constant) & & \\
\hline Responsiveness (RS) & .66 & 1.50 \\
\hline Technical Reliability (TR) & .38 & 2.64 \\
\hline Security (SE) & .48 & 2.06 \\
\hline Design (DS) & .44 & 2.25 \\
\hline Performance (PF) & .49 & 2.03 \\
\hline Incentives (IN) & .82 & 1.21 \\
\hline
\end{tabular}

Dependent Variable: Service Quality

Source: Primary Data, computed using SPSS

The test for Multicollinearity can be observed in the Table on Collinearity Statistics. Tolerance and VIF values, for different predictor variables, are shown. Since all the VIF $<10$ and Tolerance $>.1$ were satisfied, there was no multicollinearity among the predictors.

Table 17 Coefficients of the Regression Model

\begin{tabular}{|l|c|c|c|c|c|}
\hline & \multicolumn{2}{|c|}{$\begin{array}{c}\text { Unstandardized } \\
\text { Coefficients }\end{array}$} & $\begin{array}{c}\text { Standardized } \\
\text { Coefficients }\end{array}$ & t & p \\
\cline { 1 - 3 } & B & Std. Error & Beta & & \\
\hline (Constant) & 1.33 & .219 & & 6.09 & $\mathrm{p}<.05$ \\
\hline Responsiveness (RS) & .137 & .058 & .16 & 2.36 & .019 \\
\hline Technical Reliability (TR) & .163 & .074 & .20 & 2.20 & .029 \\
\hline Security (SE) & .169 & .064 & .21 & 2.63 & .009 \\
\hline Design (DS) & .073 & .069 & .09 & 1.04 & .298 \\
\hline Performance (PF) & .105 & .065 & .13 & 1.61 & .108 \\
\hline Incentives (IN) & .055 & .046 & .07 & 1.19 & .232 \\
\hline
\end{tabular}

Source: Primary Data, computed using SPSS

Unstandardized coefficients indicated how much the dependent variable varied with an independent variable when all other independent variables were held constant. The unstandardized coefficient for Responsiveness being .137, implied that for each 1-point increase in Responsiveness there was .137 points increase in Service Quality. The t values of Responsiveness $(\mathrm{t}=2.36, \mathrm{p}=.019)$, Technical Reliability $(\mathrm{t}=2.20, \mathrm{p}=.029)$ and Security $(\mathrm{t}$ $=2.63, \mathrm{p}=.009)$ were greater than two and hence their prediction of Service Quality was significant. There was an additional confirmation, with the $\mathrm{p}$ values being less than 05 . Highest $t$ value was the most significant predictor. Security was the most significant predictor of Service Quality followed by Responsiveness and Technical Reliability.

Multiple regression was run to predict Service Quality with Responsiveness, Technical Reliability, Security and Privacy, Application Design, Performance and Incentives. Responsiveness, Technical Reliability and Security were found to be significant predictors of Service Quality.

$$
\mathrm{SQ}=1.33+.169(\mathrm{SE})+.163(\mathrm{TR})+.137(\mathrm{RS})+\varepsilon
$$

The above equation was derived from the Unstandardized Coefficients from the Regression model.

\section{CONCLUSIONS}

The study was intended to analyse the relationship between Service Quality and its dimensions of Digital Banking and Payment Applications in India. The study also intended to 
find the effects of demographic factors like Gender, Income and Education on Service Quality. The following statistical tools, Descriptive statistics, t - test, ANOVA, Pearson Correlation and Multiple Regression were used to compare the effect of various demographic factors on Service Quality Dimensions.

The findings of $\mathrm{t}$ - tests did not support the idea that there was significant difference in Service Quality with Gender, Educational Qualification or Income levels. However, Private Sector Bank Users had rated higher Service Quality than Public Sector Bank Users. Correlation study revealed the effect size for Technical Reliability $\left(r^{2}=.61\right)$ and Security $\left(r^{2}=.57\right)$ and this indicated that the levels of Technical Reliability $(61 \%)$ and Security $(57$ $\%$ ) accounted for large portion of variability in Service Quality. Multiple Regression showed that $t$ values of Responsiveness $(t=2.36, p=.019)$, Technical Reliability $(t=2.20, p=.029)$ and Security $(\mathrm{t}=2.63, \mathrm{p}=.009)$ were greater than two and hence their prediction of Service Quality was significant. Therefore, Security was the most significant predictor of Service Quality, followed by Responsiveness and Technical Reliability.

\section{REFERENCES}

[1] Babu. M., Cyano Prem. A., Gayathri. J., Hariharan. C., \& Indhumathi. G., (2020) Quality of Indian E Banking Services on User's Satisfaction, Solid State Technology, 63(2), 730-737.

[2] Berry, L. L., Parasuraman, A. \& Zeithaml, V. A. (1990) Delivering Quality Service, The Free Press, New York.

[3] Chang, J. C. (2008) Taiwanese Tourists perceptions of Service Quality on Outbound Guided Package Tours: A Qualitative Examination of the SERVQUAL Dimensions, Journal of Vacation Marketing, 15(2), 164-178.

[4] Duff, A., Hair, M. \& Guo, X. (2008) Service quality measurement in the Chinese corporate banking market, International Journal of Bank Marketing, 26(5), 305 - 327.

[5] Jang, S. \& Ha, J., (2009) Perceived justice in service recovery and behavioural intentions: The role of relationship quality. International Journal of Hospitality Management, 28, 319-327.

[6] Ladhari, R. (2008) Alternative Measure of Service Quality: A Review, Journal of Managing Service Quality, 18(1), 65-86.

[7] Negi, R. (2009). Determining customer satisfaction through perceived service quality: A study of Ethiopian mobile users, International Journal of Mobile Marketing, 4(1), 31-38.

[8] Oliver, R. L. (1993) A conceptual model of service quality and service satisfaction: compatible goals, different concepts, Advances in Services Marketing and Management, 2, 65-85.

[9] Parasuraman, A., Zeithaml, V. A. \& Berry, L. L. (1985) A conceptual model of service quality and its implications for future research, Journal of Marketing, 49, 41-50.

[10] Perng, Y. H. (2007) A Service Quality Improvement Dynamic Decision Support System for Refurbishment Contractors, Total Quality Management \& Business Excellence, 18(7), 731-49.

[11] Phau. I., Rexha. N., \& Wong. D. H. (2008) Re-examining traditional service quality in an Ebanking era. International Journal of Bank Marketing, 26 (7), 526-45.

[12] Rand, G. \& Tsoukatos, E. (2006) Path analysis of perceived service quality, satisfaction and loyalty in Greek insurance, Managing Service Quality, 16, 501-19.

[13] Rashed, A. K. \& Tabassum. C. (2014) Customer satisfaction on service quality in private commercial banking sector in Bangladesh, British Journal of Marketing Studies, 2(2), 1-11

[14] Zeithaml.V. A. (2009). Service Quality, Profitability, and the Economic Worth of Customers: What We Know and What We Need to Learn, Journal of Academy of Marketing Science, 28(1), 67-85 